\title{
LESLIE SPIER, 1893-1961
}

\author{
WALTER W. TAYLOR
}

L ESLIE SPIER died on December 3, 1961. L One of the most Boasian of Boas's students, he had written on topics covering virtually the entire range of anthropology and had consistently reiterated the importance of a broad, integrated, not a narrowly atomistic view of human culture and the discipline of anthropology. In a letter written in June of 1946, he said, "Thank God that at last we have someone ... who sees that anthropology is a whole." Still earlier in another letter, he had written: "... they teach anthropology, not sociology . . . nor pseudopsychology. It's good straight anthropology and I honor them for sticking to it." Such opinions, strongly held and often bluntly presented, were typical of the man and help to explain the impact he had upon those of us who were lucky enough to have him as teacher and friend.

Spier's publications in archaeology came early and were relatively few. Yet both of his major studies are basic to much of later archaeological theory in the United States, although my experience indicates that they are strangely neglected in present-day archaeological pedagogy. I refer, of course, to his work on the Trenton gravels and his papers dealing with the prehistory of the Zuni region. In the former, he employed the devices of intra-deposit distribution and statistical probability to demonstrate that the artifacts had been deposited by geologic action, as had the gravels themselves, and that therefore there was no such thing as an "argillite culture." This method was a distinct forward step in archaeological research at the time of its publication. In a secondary paper on the same topic (review of A Pre-Lenape Site in New Jersey, p. 564), he gave us a typically "Spierian" comment: "Catchword errors have at least the virtue of rendering class characteristics conspicuous. Such an error in the work under review serves then to point out that the 'argillite culture' at Trenton cannot be used as a class caption to designate a dumping-ground for heterogeneous data."

The importance of Spier's Zuni work lies in the demonstration that, through seriation, collections of potsherds from the surface could provide data "on a par" with those obtained by stratigraphic digging. He gives credit to Kidder for the concept of seriation, to Kroeber for rank- ing and concurrent variation, and to Nelson for stratigraphy. But by using all of these techniques in conjunction with his own scientific self-discipline and clarity of thought, Spier developed his particular method and established a basic precept of archaeological theory. He was well aware (An Outline for a Chronology of Zuñi Ruins, p. 281) that he was making exposition of an important new method and that his work was fundamentally historical reconstruction (Ruins in the White Mountains of Arizona, p. 385).

But like Linton, Steward, and not a few others, Spier turned from his early interest in archaeology. Twelve of his first eighteen published papers are on archaeological subjects, while from 1919 to the end of his life he published only six more. The last of these (N. C. Nelson's Stratigraphic Technique in the Reconstruction of Prehistoric Sequences in Southwestern America, 1931) is another basic work in American archaeological theory and criticism and, in my opinion, deserves much wider reading and appreciation than it appears to have today.

One hesitates to speculate on why Spier abandoned archaeology, and I regret never having asked him his reasons for doing so. But certain fundamental changes in his viewpoint regarding anthropological goals, made explicit in his ethnographic writings and even more strongly evident in his classroom and interpersonal communications, may provide insight into this matter. I wish to say that I shall attempt this rather personal and somewhat nebulously supported analysis, not as a specific revelation of Leslie Spier, but because he is representative of a strangely widespread occurrence: the abandonment of archaeology for other subfields of anthropology by persons who were first drawn to anthropology through archaeology. Perhaps an understanding of his case may have import for an understanding of our discipline, its personnel, and their reasons for becoming anthropologists of differing stripes.

From the very first, Spier's approach to his anthropological work, both archaeological and ethnographical, seems to have been strongly culture-historical. Specifically, he was interested in historical reconstruction. He based 
his analyses on geographically wide-ranging distribution studies of minutely detailed cultural entities. Apparently, however, he gradually became dissatisfied with historical reconstruction as a research goal (Problems Arising from the Cultural Position of the Havasupai, 1929) and developed a strong doubt as to the rigor, the precision, and the breadth of the distribution studies which were the foundation of a large proportion of the culture-historical inferences being made in anthropology. In a letter of 1956 , he wrote: ". . . the general works - and even the particular ones...- are not worth much: they are not true, careful histories."

Another characteristic of Spier's approach to archaeology was his bent toward statistical treatment. But here again he evidently became disillusioned, perhaps not with the method itself but with the way in which it was being applied. I have evidence of personal communication that this was induced by his scepticism as to the validity of the culture-element tabulations being made at that time by the University of California. In a letter of November, 1936, he wrote: "Look out, statistical devices are tricky things. Unless one is a mathematician who has specialized in this particular field, it is not wise to go beyond the simple presentation of graphs and calculation of averages and variabilities. All work in correlations, probabilities, etc., - even the most simple seeming - is so tricky that it is wise to steer clear.... This is just the trouble with Kroeber's recent use of such methods in ethnology."

Thus we see a growing discontent with all the fundamental factors of his approach to archaeology and even, perhaps, with historical reconstruction itself as a goal of anthropological research. If, therefore, as he seems to have done when he began his career, he believed that archaeology was largely a matter of historical reconstruction and that the statistical manipulation of detailed distribution studies was the most likely and productive method, then it is not difficult to see how and why he became disenchanted with the field of archaeology. Evidence of the same sort of reaction can be seen in the writings and actions of other archaeologically disillusioned anthropologists: uncertainty as to the value of the only goals envisaged and doubt as to the efficacy of the only methods employed.

But let it not be supposed that Leslie Spier's influence on archaeology ended or even appreciably diminished with the termination of his archaeological publication. Just as he was forever denying, in more formal utterances, the value of the strictly theoretical and, at the same time, giving vast amounts of (some of the best) theory in his more informal communications, just so was he constantly presenting to his students informal yet most cogent advice on all sorts of archaeological matters, while no longer making any formal contributions to that field. Speaking for myself, I know very well that he had a profound influence on my archaeological thinking and on that of many of my contemporaries, not merely in the form of anthropological generalities, but in many very specific and uniquely archaeological ways. As a dedicated disciple of Franz Boas, Leslie Spier was a "whole man," both personally and professionally, as anthropologist and as friend. David Mandelbaum has said (The Eastern Anthropologist, in press) that he was "an anthropologist's anthropologist." I should like to say with every sincerity that he was, in my own fortunate experience, a student's archaeologist.

\section{Archaeological Bibliograpyy of Lestie Spier}

1913 Results of an Archaeological Survey of the State of New Jersey. American Anthropolosist, Vol 15, No. 4, pp. 675-9. Lancaster.

Review: On the Shell Heaps of Maine. F. B. Loomis and D. B. Young. American Anthropologist, Vol. 17, No. 2, pp. 346-7. Lancaster.

Location of Archaeological Remains on Manhattan Island. In "The Indians of Manhattan Island and Vicinity," by Alanson Skinner. American Museum of Natural History, Guide Leaflet Series, No. 41, pp. 42-52. New York.

Indian Remains near Plainfield, Union County, and along the Lower Delaware Valley. Geological Survey of New Jersey, Bulletin 13, pp. 75-99. Union Hill, N. J.

1916 New Data on the Trenton Argillite Culture. American Anthropologist, Vol. 18, No. 2, pp. 181-9. Lancaster.

Review: Compositions of California Shellmounds. Edward Winslow Gifford. American Anthropologist, Vol. 18, No. 2, pp. 282-4. Lancaster.

Review: A Pre-Lenape Site in New Jersey, E. W. Hawkes and Ralph Linton. American Anthropologist, Vol. 18, No. 4, pp. 564-6. Lancaster.

1917 Zuñi Chronology. Proceedings of the National Academy of Sciences, Vol. 3, pp. 280-3. Washington.

An Outline for a Chronology of Zuñi Ruins. Anthropological Papers, American Museum of Natural History, Vol. 18, Pt. 3, pp. 207-331. New York.

1918 Notes on Some Little Colorado Ruins. Anthropological Papers, American Museum of Natural History, Vol. 18, Pt. 4, pp. 333-62. New York.

The Trenton Argillite Culture. Anthropological Papers, American Museum of Natural History, Vol. 22, Pt. 4, pp. 167-226. New York. 
1919 Ruins in the White Mountains of Arizona. Anthropological Papers, American Museum of Natural History, Vol. 18, Pt. 5, pp. 363-87. New York.

1926 Review: Archaeological Investigations in the Aleutian Islands. Waldemar Jochelson. Washington Historical Quarterly, Vol. 17, p. 145. Seattle.

1927 (With Dorothy A. Smith) The Dot and Circle Design in Northwestern America. Journal de la Société des Americanistes de Paris, Vol. 19, pp. 47-55. Paris.

1928 Concerning Man's Antiquity at Frederick, Oklahoma. Science, Vol. 67, No. 1728, pp. 160-1. New York.
A Note on Reputed Artifacts from Frederick, Oklahoma. Science, Vol. 68, No. 1756, p. 184. New York.

1930 Review: The Prehistory of Aviation. Berthold Lit1fer. American Anthropologist, Vol. 32, No. 3, pp. 556-7. Menasha.

1931 N. C. Nelson's Stratigraphic Technique in the Reconstruction of Prehistoric Sequences in Southwestern America. In Methods in Social Science, edited by Stuart A. Rice, pp. 275-83. The University of Chicago Press, Chicago.

SOUTHERN ILLINOIS UnIVERSTTY Carbondale, Illinois September, 1962 